\title{
Wspomnienie o Profesorze Wojciechu Sokolewiczu
}

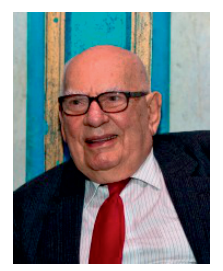

Nie budzi wątpliwości, że dzień 13 marca 2012 roku trwale zapisze się w nauce polskiego prawa, w szczególności prawa konstytucyjnego. Tego dnia odszedł do wieczności jeden z najwybitniejszych polskich prawników, luminarz nauki prawa konstytucyjnego, Profesor Wojciech Sokolewicz. Dla najbliższych kochający mąż, ojciec i dziadek, dla przyjaciół Wojtek, dla pozostałych Profesor Sokolewicz. Bez względu na stopień zażyłości i relacje w jakich z Nim pozostawaliśmy, dla całego grona polskich prawników pozostanie niewątpliwym autorytetem, zaś dla młodszego pokolenia koleżanek i kolegów - punktem odniesienia i wzorem do naśladowania.

Zadaniem niemożliwym do zrealizowania byłoby kompletne ujęcie w ramy kilkunastostronicowego wspomnienia niezwykle bogatego życiorysu Profesora Sokolewicza. Toteż autorzy postawili sobie odmienne zadanie. W ramach niniejszego artykułu pragną zwrócić uwagę na te aspekty życia Profesora, które większości z Nas, zwłaszcza osobom pozostającym z Nim w bliskich relacjach są dobrze znane i w których mogliśmy bezpośrednio lub pośrednio uczestniczyć.

Wojciech Sokolewicz urodził się 27 marca 1931 roku w Warszawie. Jego życiorys naukowy - bo od tego wypada zacząć - jest niezwykle barwny i złożony. Po ukończeniu w 1954 roku studiów prawniczych na Wydziale Prawa Uniwersytetu Warszawskiego Wojciech Sokolewicz kontynuował i rozwijał swoje pasje naukowe wiążąc się z Polską Akademią Nauk. Owocem prowadzonych badań i analiz były kolejne dzieła, na podstawie których uzyskał w 1964 roku stopnia doktora, zaś w 1968 roku doktora habilitowanego nauk prawnych. Obie Jego dysertacje - doktorska i habilitacyjna - poruszały różne aspekty funkcjonowania Rad Narodowych. W 1974 roku uzyskał stano- 
wisko profesora nadzwyczajnego, zaś w 1987 roku został mianowany profesorem zwyczajnym.

Swą ogromną wiedzę i wybitny warsztat naukowy Profesor Sokolewicz z powodzeniem wykorzystywał pełniąc wysokie funkcje w wielu organach i instytucjach państwowych. W latach 1984-1992 był członkiem Rady Legislacyjnej przy Prezesie Rady Ministrów. Pracował również jako doradca w Kancelarii Rady Państwa, Kancelarii Prezydenta Rzeczypospolitej Polskiej oraz w Biurze Studiów i Ekspertyz Kancelarii Sejmu. W latach 19901991 pozostawał stałym ekspertem Komisji Konstytucyjnej Sejmu X kadencji. Aktywnie uczestnicząc w obradach Okrągłego Stołu tworzył rudymenty przyszłego ustroju Rzeczypospolitej Polskiej. W 1993 roku został powołany na stanowisko sędziego Trybunału Konstytucyjnego które piastował do 1999 roku, kiedy to zrezygnował z niego. Będąc sędzią Trybunału w okresie intensywnych zmian ustrojowych i wieńczącego je uchwalenia Konstytucji Rzeczypospolitej Polskiej, współtworzył ówczesne orzecznictwo TK, w znacznym stopniu wpływając na wykładnię nowej ustawy zasadniczej. Wespół z innymi wybitnymi konstytucjonalistami zasiadającymi w Trybunale Profesor Sokolewicz kształtował nowe realia ustrojowe państwa polskiego, w szczególności dokonując wykładni zasad naczelnych Konstytucji Rzeczypospolitej Polskiej, m. in. zasady demokratycznego państwa prawnego. Do swej pracy w Trybunale Profesor podchodził ze znacznym dystansem i skromnością, wspominając po latach, iż było to w Jego życiu niezwykle kształcące i ciekawe doświadczenie.

Niemal przez całe swoje naukowe, twórcze życie Profesor Sokolewicz był związany z Instytutem Nauk Prawnych Polskiej Akademii Nauk, pełniąc w nim różnorodne funkcje. W latach 1969-1974 był zastępcą Dyrektora Instytutu i kierownikiem zespołu badań nad instytucjami i doktrynami polityczno-prawnymi Stanów Zjednoczonych Ameryki. Od 1983 do 1992 roku pozostawał w Instytucie kierownikiem zespołu prawa konstytucyjnego. Poza działalnością w Polskiej Akademii Nauk Profesor Sokolewicz należał również do Zrzeszenia Prawników Polskich, był członkiem Polskiego Towarzystwa Prawa Konstytucyjnego oraz członkiem-korespondentem Międzynarodowej Akademii Prawa Porównawczego w Paryżu.

Poza licznymi znakomitymi publikacjami kunszt naukowy Profesora Sokolewicza przejawiał się również w sporządzanych recenzjach wydawniczych książek, recenzjach rozpraw doktorskich i habilitacyjnych oraz opiniach 
w sprawie nadania tytułu naukowego profesora. Profesor sporządził przeszło pięćdziesiąt takich recenzji, wnosząc w ten sposób znaczny wkład w kształcenie kadry naukowej i podnoszenie kwalifikacji przez młodsze pokolenie naukowców. Pozostawał przy tym recenzentem życzliwym, ale krytycznym. Swoje spostrzeżenia formułował w sposób jasny i klarowny. Wnikliwie analizując recenzowane prace Profesor potrafił dostrzec nawet najdrobniejsze uchybienia i niedoskonałości. W swych cennych i trafnych uwagach Profesor skupiał się na istocie rzeczy, izolując ją od pozostałych, mniej znaczących treści. Nigdy nie narzucał autorom swoich koncepcji, sugerując jedynie dokonanie stosownych modyfikacji w kilku możliwych, wskazanych Przezeń kierunkach. O wybitnym warsztacie naukowym Profesora świadczy również rozmiar przygotowywanych recenzji. Jego uwagi nigdy nie były zbyt obszerne. Swe spostrzeżenia formułował w sposób oszczędny i skondensowany, z zachowaniem jednak wszelkich kanonów potrzebnych do należytego przeprowadzenia procedury.

Poza działalnością naukową Profesor Sokolewicz był również wybitnym dydaktykiem. Jego wykłady z prawa konstytucyjnego cieszyły się ogromną popularnością wśród studentów. Profesor przekazywał wiedzę w sposób niezwykle jasny i klarowny, tak, że nawet najbardziej powikłane treści mogły być swobodnie przyswajane przez Jego słuchaczy. Był egzaminatorem wymagającym ale sprawiedliwym. Zgodnie z łacińską premią - suum cique tribuere - każdemu oddawał tyle, ile mu się należało. Wysoko cenił przy tym egzaminy ustne. Choć wymagało to podjęcia znacznego wysiłku, o wiele większego aniżeli w przypadku egzaminów pisemnych, Profesor z uśmiechem i życzliwością przyjmował ten trud. Dla studentów Profesora Sokolewicza egzamin z prawa konstytucyjnego był znaczącym przeżyciem. Po części wynikało to $\mathrm{z}$ wymagań stawianych przez egzaminatora. Wydaje się jednak, że zasadniczym tego powodem był osobisty kontakt młodych ludzi z tak dostojną osobistością. W przeprowadzanych przez Profesora egzaminach częstokroć towarzyszyli $\mathrm{Mu}$ Jego wychowankowie, zdobywając w ten sposób cenne i kształcące doświadczenia.

$\mathrm{Na}$ pozycję i autorytet Profesora Sokolewicza w gronie polskich prawników-konstytucjonalistów wpływało kilka czynników. Niewątpliwie najważniejszym z nich był Jego wybitny dorobek i warsztat naukowy. Nauka pozostawała zasadniczą determinantą życia Profesora. Podporządkował jej wszelkie inne sfery swej aktywności. Pozostawał przy tym naukowcem nie- 
zwykle systematycznym i sumiennym. Wypracował w sobie nawyk, który $\mathrm{z}$ czasem urósł do rangi istotnej przyjemności życiowej, aby każdego dnia przemyśleć lub opisać choć jedno zagadnienie w ramach kolejnej przygotowywanej publikacji. W ten sposób przez całe swoje twórcze życie dążył do samodoskonalenia, optymalnie wykorzystując swoją wiedzę i kunszt naukowy.

Kolejnym czynnikiem wpływającym na pozycję Profesora była Jego nietuzinkowa osobowość, niezwykła charyzma oraz ciepłe i życzliwe podejście do ludzi. Te cechy powodowały, że Profesor pozostawał zawsze w centrum zainteresowania, zaś głoszone przez Niego poglądy nigdy nie napotykały obojętności Jego słuchaczy. Choć niektóre z nich mogły wzbudzać kontrowersje, bez wątpienia stanowiły podstawę do gębszych rozważań i dywagacji. Profesor unikał przy tym w Swoich wywodach i analizach problemów marginalnych, mało znaczących dla nauki, skupiał się na istocie rzeczy, umiejętnie ją eksponując. Podejmując polemikę z młodszymi przedstawicielami nauki zawsze sięgał po argumenty merytoryczne, nigdy nie podkreślał różnicy wieku ani autorytetu i dorobku naukowego, którym wszak mało kto był w stanie Mu dorównać.

Pomimo ogromnego autorytetu, jakim cieszył się w kręgach naukowych, Profesor Sokolewicz bynajmniej nie dystansował się od ludzi, nie budował barier względem otoczenia. Przeciwnie, był człowiekiem niezwykle towarzyskim, potrafiącym cieszyć się życiem i zeń korzystać. Wielokrotnie potwierdzał to zwłaszcza podczas bankietów, kolacji i nieformalnych spotkań towarzyszących konferencjom naukowym. Dysponował umiejętnością nawiązywania konstruktywnych konwersacji, czemu pomagało Jego inteligentne, niekiedy nieco sarkastyczne poczucie humoru. Te cechy zestawione $\mathrm{z}$ dostojną postawą Profesora oraz jego donośnym, charakterystycznym głosem powodowały, że pozostawał „duszą towarzystwa”.

Swoją osobą Profesor Sokolewicz przez dziesiątki lat uświetniał doroczne Ogólnopolskie Zjazdy Katedr i Zakładów Prawa Konstytucyjnego. Uczestniczył w nich niemalże od samego początku przez przeszło pięćdziesiąt lat, wielokrotnie pełniąc należny Mu honor przewodniczenia obradom. Potrafił przy tym formułować zaiste mistrzowskie konkluzje i spostrzeżenia, tworząc znakomity przyczynek do dalszej dyskusji i konstruktywnej polemiki.

Nauka była wielką pasją Profesora. Pasja ta z powodzeniem udzielała się młodszym naukowcom, którzy w Jego osobie widzieli wzór do naśladowa- 
nia, swego orędownika oraz autorytet. Stąd jednym z istotnych elementów życia Profesora był wkład w rozwój i kształcenie młodych naukowców. Był przy tym opiekunem i nauczycielem wymagającym, nie szczędząc słów tak cennej, konstruktywnej krytyki. Czynił to jednak w sposób niezwykle życzliwy, aby - jak zwykł mawiać - nie zagasić iskry, która tli się w sercu i umyśle młodego człowieka. Z zainteresowaniem obserwował rozwój młodej kadry naukowej, dzieląc się swą wiedzą i doświadczeniem. W sposób szczególny mogli to docenić doktoranci Profesora, mający przywilej i zaszczyt pracować i zdobywać wiedzę u Jego boku. Profesor nigdy nie budował barier międzyludzkich, przeciwnie, $\mathrm{z}$ wieloma młodymi naukowcami pozostawał $\mathrm{w}$ bliskich, niekiedy wręcz przyjacielskich relacjach. To charakterystyczne, pełne życzliwości podejście wytwarzało wokół Niego specyficzną, pozytywną aurę.

Profesor Sokolewicz posiadał rozliczne pasje, które pielęgnował i rozwijał przez całe swoje życie. Pośród nich poczesne miejsce zajmowała literatura. Profesor był wielkim miłośnikiem czytania, z uwagą zgłębiał każdą kolejną lekturę, która trafiała do jego prywatnej domowej biblioteki. W ciągu Swojego życia Profesor zgromadził niespełna dziesięć tysięcy książek. Nie było osoby, która odwiedzając Go w domu nie zwróciła uwagi na imponujący zbiór biblioteczny, który pokrywały w zasadzie każdą wolną powierzchnię ścienną. Większość z tych książek, były to dzieła powiązane z zainteresowaniami badawczymi Profesora. Nie była to jednak literatura wyłącznie polska. Będąc wybitnym naukowcem - poliglotą profesor gromadził i zgłębiał także książki zagraniczne m. in. amerykańskie, rosyjskie, francuskie, czeskie oraz słowackie.

Poza literaturą Profesor fascynował się również muzyką, zwłaszcza polskimi utworami z lat '40, '50, '60 i '70. Posiadał obszerną kolekcję płyty CD z której wielokrotnie czynił znakomity użytek podczas spotkań z przyjaciółmi. Goście Profesora mogli posłuchać Jego ulubionych utworów, niekiedy wspólnie nucąc je przy szklaneczce szlachetnego trunku. Mogli również zwłaszcza mając zaszczyt być zaproszonymi na obiad czy kolację - podziwiać imponujący widok i panoramę okolicy z ogromnego okna salonowego w mieszkaniu Profesora na warszawskim Wilanowie.

Jedną z pasji, której Profesor oddawał się niemalże do końca życia, był sport i zachowanie aktywności fizycznej. Kiedy tylko zdrowie na to pozwalało, Profesor udawał się na basen. W okresie wiosenno - jesiennym znacz- 
ną część Swojego wolnego czasu spędzał na łonie przyrody, na działce pod Warszawą. Organizował tam również spotkania przy grillu dla swoich przyjaciół, wychowanków i podopiecznych.

Chociaż Profesora Sokolewicza nie ma już pośród nas, nieustannie pozostaje obecny w pamięci Swych przyjaciół, koleżanek, kolegów oraz uczniów. Wyrazem tej obecności są liczne wspomnieniach o Profesorze przygotowane przez przedstawicieli nauki prawa konstytucyjnego, osoby, które pozostawały z Nim w bliskich relacjach. Oto niektóre z nich:

\section{Wspomnienie Profesora Jana Wawrzyniaka}

„Szanowny Profesorze, Drogi Przyjacielu, Wojtku,

Przed kilkoma miesiącami miałem zaszczyt i przyjemność przemawiać na uroczystości ku Twojej czci zorganizowanej z okazji 80. rocznicy urodzin. Podobny zaszczyt i przyjemność były moim udziałem przed dziesięciu laty, gdy obchodziłeś 70. urodziny. Byłem przekonany, że - w myśl porzekadła do trzech razy sztuka - za kilka lat będę podobnie czcił Twoje 90. urodziny.

Okrutny los chciał inaczej. Dzisiaj nie niegdysiejszy zaszczyt i przyjemność, ale wielki żal i smutek są dominantą tego co czuje przemawiając nad Twoim grobem w imieniu Instytutu Nauk Prawnych Polskiej Akademii Nauk.

Byłeś przecież cały czas aktywny, twórczy, pracowity. Liczyliśmy wszyscy - Twoi przyjaciele, koleżanki, koledzy na kolejne dzieła, jak zwykle znakomicie skonstruowane, erudycyjne, przekonywujące, pisane piękną, rzadko już spotykaną polszczyzną. Popełniłeś ich przecież wiele i pracowałeś nad nimi do końca.

Gros tych dzieł powstało, było bardziej lub mniej związanych z Instytutem, w którym przepracowałeś niemal całe Swoje naukowe, twórcze życie. Dzięki Twojej aktywności badawczej, dydaktycznej, organizacyjnej stałeś się - jeśli można tak powiedzieć - konstytucyjną twarzą Instytutu Nauk Prawnych. Jesteśmy Ci za to niezmiernie wdzięczni. Będzie nam tej twarzy bardzo brakowało.

Możemy się jedynie pocieszać «żeś nie wszystek umarł». Pozostał Twój wspaniały dorobek naukowy, który będzie przykładem twórczości w dziedzinie prawa konstytucyjnego, dla młodszego pokolenia badaczy. 
Dziękujemy Ci za wszystkie dokonania naukowe, za życiowy wigor tak sympatycznie zaraźliwy.

Nie da się ukryć, że nie tylko Instytut Nauk Prawnych po Twoim odejściu będzie uboższy o Twoją wybitną, kreatywna osobowość oraz o Jej pozytywne oddziaływanie na otoczenie na nas wszystkich".

\section{Wspomnienie Profesora Waldemara Wołpiuka}

Rak, ryba i inne ingrediencje

„Niewiele osób w naszym środowisku wie o tym, że Wojtek Sokolewicz był nie tylko absolwentem prawa, ale studiował dziennikarstwo i pisywał teksty publicystyczne. Znajomość warsztatu dziennikarskiego, zamiłowanie doń i wyniesione zeń nawyki dawały o sobie znać w jego aktywności naukowej. Wiedliśmy ze sobą niekiedy trudne rozmowy, gdy Wojtek skręcał w swojej twórczości w stronę eseistyki czemu się przeciwstawiałem. Nie jestem pewien czy miałem wówczas rację, zwłaszcza, że argumentem podnoszonym przez Wojtka była chęć «uczłowieczenia» tekstów naukowych oraz lepsze komunikowanie się z potencjonalnymi odbiorcami jego myśli konstytucyjno-prawnych. Wojtek - co było jego indywidualną zdolnością - wykazywał znakomitą umiejętność wychwytywania spośród szczegółowych zagadnień spraw najważniejszych i akcentowania ich poprzez treść tytułów jego opracowań. Znane są nam wszystkim jego fundamentalne studia o jakże znamiennych i niepospolitych dla doktryny prawa tytułach: Rozdzielone leczczy równe? Legislatywa i egzekutywa w Małej Konstytucji 1992 r.; Czy strażnikowi potrzebna jest toga? (artykuł recenzyjny o książce L. Garlickiego: Sądownictwo konstytucyjne w Europie Zachodniej); Czy rak może być ryba a Trybunat sądem? To zaledwie niektóre z prac niezwykle popularnych, docenionych przez specjalistów z dziedziny prawa konstytucyjnego, oddziałujących na poglądy naszego środowiska naukowego i wielokrotnie cytowanych. W 1990 roku będąc organizatorem konferencji międzynarodowej, której uczestnikami byli uczeni ze Wschodu i Zachodu, trapiłem się jaki tytuł nadać książce, zawierającej pokonferencyjne referaty. Pojawiały się formalistycznie brzmiące projekty tytułów, które wprawdzie oddawały treść książki ale składały się ze skomplikowanej konstrukcji słownej. Koncepcja nazewnicza Wojtka była najprostsza: Prawo na Zachodzie. Pod tym tytułem wydana przez Ossoli- 
neum książka, cieszyła się dużym zainteresowaniem środowiska prawniczego. Mylące byłoby jednak mniemanie, że tego rodzaju wybór tytułów miałby świadczyć o publicystycznym traktowaniu przez Wojtka podejmowanych przez Niego tematów badawczych lub o nadmiernej swobodzie Jego warsztatu naukowego. Było bowiem przeciwnie, każdy badany przez Niego problem rozpatrywany był bardzo wnikliwie. Skrupulatnie, niekiedy przez wiele lat gromadził niezbędne dane (tak było na przykład z przygotowywaniem materiałów do książki Prasa i konstytucja oraz do książki o prawach kobiet). Przejawiał dużą dbałość o szczegóły, konfrontował dane pierwotne z innymi źródłami i informacjami, dążąc do rzetelnej falsyfikacji tez badawczych. Wszyscy podziwialiśmy Jego trud wkładany w dokumentowanie przedstawianych przez Niego poglądów. Wyrazem tego były zamieszczane w Jego pracach rozbudowane przypisy o charakterze rozszerzającym, dygresyjne i polemiczne. Stanowi to niewątpliwy dowód, że w prowadzonej przez Wojtka działalności naukowej przenikliwości myślenia, nierozłącznie towarzyszyła wielka staranność i pracowitość".

\section{Wspomnienie Profesora Eugeniusza Zwierzchowskiego}

„Odszedł od nas znakomity uczony, konstytucjonalista. Dla najliczniejszych szanowany, wybitny profesor, dla innych starszy kolega lub Mistrz, zaś dla mojego pokolenia - Przyjaciel.

Należał do pokolenia, któremu czas okupacji niemieckiej przyniósł w wieku poniżej 15 lat dojrzałą rolę konspiratora «Szarych Szeregów», a po upadku Powstania Warszawskiego wywóz na przymusowe roboty do Niemiec.

Powrót i życie oraz nauka w zburzonej Warszawie były niełatwe i wymagały hartu oraz wyrzeczeń. Budował normalne życie Stolicy, zaś pobierając nauki w szkole średniej i w czasie uniwersyteckich studiów prawniczych i dziennikarskich budował również swoją przyszłość.

Ukształtowany przez harcerską tradycję, aktywnie działał w ruchu młodzieżowym, a więc w: ZHP, ZWM «Wici», «ZAMP-ie». To prawdopodobnie ta młodzieżowa działalność dała Mu później, w wieku już dojrzałym, obserwowaną na naukowych konferencjach wyjątkową łatwość nawiązywania kontaktów z młodym pokoleniem konstytucjonalistów. 
U progu kariery zawodowej szukał miejsca dla Siebie. Nauka była wówczas tylko jedną z Jego dróg. Pierwsze kroki w nauce stawiał w kontakcie ze znakomitym administratywistą Maurycym Jaroszyńskiem. «Zdradził» Swojego pierwszego mistrza na rzecz wybitnego konstytucjonalisty Stefana Rozmaryna. Nie znam okoliczności owej «zdrady», ale myślę, że jedną z ważnych przyczyn mogła być potrzeba szerszych i bardziej różnorodnych horyzontów myślenia prawniczego. Przemawia za tym zarówno późniejszy styl pisarski, jak również Jego szybko rosnący dorobek naukowy.

Oprócz intelektualnej bystrości i warszawskiej zawadiackości, cechowała Go również niezwykła pracowitość. Opowiadał mi, że podczas jednego z pobytów, aby maksymalnie wykorzystać tamtejsze zbiory, uzyskał zgodę na zamykanie się na noc w bibliotece, bo wówczas miał swobodny dostęp do zbiorów, a także kserograf był wolny.

Jak nieomal każdy mężczyzna lubił: «wino, kobiety i śpiew». To nie alegoria. Jedna z naszych koleżanek, w kontekście tytułu Jego Księgi Jubileuszowej Konstytucja i władza, wyraziła myśl, że ów tytuł powinien brzmieć Konstytucja, kobiety i władza.

Mówi się, że nie ma ludzi nie zastąpionych. Może przy łopacie, ale nie w nauce. Osobowości i klimatu, który roztaczał Wojciech Sokolewicz nikt nie zastąpi. Po prostu - staliśmy się ubożsi”.

\section{Wspomnienie Państwa Agnieszki i Leszka Garlickich}

„Wojciech Sokolewicz był wybitnym konstytucjonalistą, znawcą zarówno polskiego, jak i zagranicznego prawa konstytucyjnego, autorem bądź redaktorem licznych dzieł obejmujących zagadnienia ustrojowe chyba wszystkich najważniejszych systemów na świecie. Zawsze zadziwiała Jego erudycja, podbudowana wszechstronną i głęboką wiedzą oraz znajdująca oparcie w znajomości języków, tak wschodniego, jak i zachodniego świata. Był też - gdy bieg wydarzeń politycznych już na to pozwolił - wybitnym sędzią, prekursorem wielu nowych rozwiązań orzeczniczych i bardzo szkoda, że los (a zwłaszcza kwestie zdrowotne) nie pozwoliły Mu dokończyć kadencji w Trybunale Konstytucyjnym.

Nie nad tymi jednak, powszechnie znanymi i szeroko już opisanymi faktami z Jego życia chciałbym się tutaj zatrzymać. To bowiem, co wydaje mi się 
najważniejsze, to niezwy-kle bogata, wielowymiarowa osobowość Wojciecha, czyniąca właściwie niemożliwym proste jego zaszufladkowanie. Większość Jego życia przypadła, niestety, na «ciekawe czasy». Mord katyński pozbawił go Ojca, powstanie warszawskie rzuciło na roboty do niemieckiego jeszcze Wrocławia, a inteligenckie pochodzenie nie dało łatwego startu w początku powojennej rzeczywistości. Te doświadczenia i sprzeczności ukształtowały Jego osobowość, splatając się w niezwykle skomplikowaną i trudną do rozszyfrowania całość. Dopiero ci, którzy poznali Go lepiej, potrafili się przebić przez barierę sarkastycznego i wyrafinowanego humoru i zrozumieć rzeczywisty wyraz Jego umysłowości i sposobu postrzegania świata. Takie przebicie się nie było jednak łatwe, bo Wojciech nie tolerował głupoty, ograniczenia umysłowego i chamstwa, a to nie ułatwiało $\mathrm{Mu}$ życia w otaczającym Go środowisku.

Zawsze przy tym chciał żyć naprawdę, szukać spełnienia nie tylko w formułowaniu nowych koncepcji konstytucyjnych, ale także w bardziej epikurejsko pojmowanym systemie wartości. Był, jak to kiedyś określił jeden z naszych kolegów z Tybingi, człowiekiem baro-kowym, postacią pamiętaną nie tylko z gabinetów seminaryjnych czy sal sądowych.

Za wiele jawi się szczegółowych wspomnień, by choćby zasygnalizować to wszystko, co pozostaje nam w pamięci po ponad czterdziestu latach znajomości i przyjaźni z Wojcie-chem. Wspólne wyjazdy na konferencje naukowe i zjazdy katedr, na których niekoniecznie tylko części referatowe zapisały się w zbiorowej świadomości środowiska. Różnego rodzaju spotkania i imprezy towarzyskie, zawsze ochoczo organizowane przez Wojciecha i Wandę, już to w ich wilanowskim mieszkaniu, już to na «daczy» pod Kołbielą. A może przede wszystkim, spotkania na wakacjach, zwłaszcza nad morzem w Białogórze, gdzie Państwo jeździli regularnie przez wiele lat.

Z owych nadmorskich wyjazdów pamiętam zwłaszcza okres wczesnych lat dziewięć-dziesiątych, gdy towarzyszył nam też pies Wojciecha, zwany oficjalnie Maksem, a - mniej formalnie - Komuchem. Wielkie wrażenie robiło na ludziach, gdy Wojciech, wtedy w świet-nej formie, zawsze dobrze ubrany i pańsko wyglądający, wołał gromkim głosem «Komuch do nogi», a niekiedy dodawał jeszcze bardziej szczegółowe określenia owego Komucha. Czasem nie tylko pies reagował na te wezwania.

W owym czasie jeździliśmy nad morze z dużą gromadką młodszych i starszych dzieci, a Wojciech wiele czasu poświęcał na opowiadanie im ba- 
jek, zagadek i historyjek. Wymagało to dużej czujności, zwłaszcza ze strony matek (szczególnie piosenka o pewnej księżniczce rodziła poważne problemy cenzuralne), ale do dzisiaj owe dzieci - teraz już dorosłe prawniczki i prawnicy, pamiętają niektóre pointy, nawet jeżeli ich pełne zrozumienie przychodziło dopiero po latach.

Dał się też Wojciech poznać w miejscowej knajpie, dzisiaj przekształconej w sympa-tyczną restaurację, ale wtedy nadal adresowanej przede wszystkim do pracowników upadają-cej spółdzielczości rolnej. Prowadził on tam różnego rodzaju debaty polityczno-obyczajowe, a gdy pewnego razu w kwestie historycznej przeszłości regionu, tylko naszej interwencji zawdzięczał szybką ewakuację.

Wojciech lubił i umiał się bawić, choć innym nie zawsze było łatwo dotrzymać Mu kroku. Ale owe zabawy i uciechy służyły tylko ekstrenalizacji Jego osobowości - a za nimi odkryć było można Człowieka wrażliwego, przyjaznego innym, odrzucającego agresję, złość, zazdrość i nienawiść. Życie nauczyło go, że to co nie jest białe, niekoniecznie musi być od razu czarne (bądź czerwone) i że nawet jeżeli coś naprawdę czarne, to nie musi być przez sam ten fakt odrażające. Ale żeby dojść do takiej filozofii tolerancji i zrozumienia konieczne było nie tylko - czasem bardzo trudne - doświadczenie życiowe, ale także wysoki iloraz inteligencji i wrodzona dobroć serca.

Będzie nam Wojciech brakowało i będziemy Go wspominać nie tylko w dyskusjach naukowych i cytatach orzeczniczych, ale także, a może nawet - przede wszystkim, gdy bę-dziemy Go przywoływać jako człowieka, który zawsze potrafił żyć pełnią swego życia”.

\section{Wspomnienie Profesora Piotra Tulei}

„Profesora Wojciecha Sokolewicza poznawałem w zasadzie trzy razy. Najpierw jako student i asystent poznałem publikacje profesora Sokolewicza. Był jednym z autorów, którego prace spowodowały moje zainteresowanie prawem konstytucyjnym. Po raz pierwszy spotkałem Profesora w 1989 r. na Zjeździe Katedr i Zakładów Prawa Konstytucyjnego w Kołobrzegu. Ten Zjazd Katedr pamiętam do dzisiaj, głównie ze względu na obecność Profesora Sokolewicza, który był wtedy duszą towarzystwa. I wreszcie w 1993 roku spotkałem Profesora w Trybunale Konstytucyjnym. Zostałem asystentem 
sędziego Wojciecha Sokolewicza. Profesor, który w kontaktach prywatnych był jowialny, tryskał humorem i zachowywał dystans do bieżących wydarzeń, okazał się wymagającym patronem. Przygotowując projekty orzeczenia zawsze określał problemy, jakie należało rozwiązać i ustalał spsób ich rozwiązywania. Precyzyjnie formułował swe oczekiwania w stosunku do asystentów. Wymagał kreatywnego podejścia do pracy. Swoim współpracownikom w Trybunale Konstytucyjnym starał się ukazać złożoność spraw, które należało rozstrzygnąć. Miał ogromną wiedzę teoretyczną i praktyczną nie tylko z zakresu prawa konstytucyjnego ale również z innych gałęzi prawa. Współpraca z Profesorem Sokolewiczem była dla mnie świetną szkołą. Dzięki niemu nabyłem umiejętności niezbędne do pracy w Trybunale Konstytucyjnym, których nie można zdobyć zajmując się tylko doktryną prawa. Niestety naszą współpracę przerwała choroba Profesora.

Później wielokrotnie miałem okazje spotykać Profesora Sokolewicza. Zawsze pytał o moje plany, zamierzenia, publikacje. Wnikliwie je oceniał i służył radą. Regularnie spotykaliśmy się przy okazji wykładów organizowanych w Trybunale Konstytucyjnym. Od kilku lat Profesor przychodził na te wykłady z dr Leną Kondratiewą - Bryzik. Traktował ją jak córkę. Oboje byli stałymi gośćmi wykładów i aktywnymi uczestnikami kuluarowych dyskusji odbywających się po wykładach. W trakcie jednej z takich dyskusji zrodził się pomysł zaproszenia dr Leny Kondratiewej - Bryzik do Krakowa. Profesor odradzał jej wyjazd, twierdząc, że powinna się skupić na przygotowywaniu publikacji naukowych. Nie mógł pogodzić się z jej śmiercią i przeżył ją zaledwie o tydzień".

\section{Wspomnienie Profesora Wiesława Skrzydly}

„W mojej pamięci wśród wielu cech, które wyróżniały Profesora Wojciecha Sokolewicza została szczególnie jedna - Człowieka wielkiej życzliwości wobec młodych ludzi parających się nauką. Doświadczyłem tego osobiście w początkach mojej kariery naukowej, a więc w latach naszej młodości. Istnienie tej cechy potwierdziły moje obserwacje. Nasze drogi spotykały się także w składzie redakcji «Państwa i Prawa» a także w «Problemach Rad Narodowych». Pouczające były rozmowy Profesora z młodymi autorami, którzy nie mając doświadczenia napotykali na pewne trudności, szczególnie 
na starcie. Z tych rad, pomocy i życzliwości korzystało wielu młodych ludzi, przyzwyczajonych przez Niego do stawiania sobie ambitnych celów i pokonywania przeszkód oraz trudności.

Życzliwie wspierał młodych autorów jako promotor, współautor niektórych prac, jako redaktor naukowy włączał się w skład zespołów autorskich przygotowujących prace zbiorowe. Jego brak będziemy dotkliwie odczuwali”.

\section{Wspomnienie Profesora Zbigniewa Witkowskiego}

„Pamiętam śp. prof. Sokolewicza od pierwszej chwili, gdy pojawiłem się jako młodziutki asystent w 1977 r. na zjeździe Katedr Prawa Państwowego w Ustroniu k. Kępna, organizowanej przez ośrodek łódzki. Dystyngowany Pan w okularach z lekko zaznaczającym się już tzw. brzuszkiem piwnym, w jasnym letnim, sportowym garniturze i z nieodłącznie narzuconą na ramiona marynarką. Wtedy jeszcze Pan docent Sokolewicz. I pamiętam Jego znakomite wypowiedzi podczas konferencji, konkretne, merytoryczne zawsze wypowiadane $\mathrm{z}$ lekkim dystansem wobec tego co «szalało na zewnątrz». Pamiętam też Jego świetne relacje z wprawdzie młodszymi nieco kolegami np. prof. Leszkiem Garlickim. Widać było ich wielką sympatię, ale i żarciki wygłaszane wzajemnie, które pewnie były zrozumiałe tylko dla nich samych i pewnego kręgu wtajemniczonych. To co mnie od razu uderzyło u Sokolewicza, to Jego ciepły stosunek do młodych adeptów sztuki. W odróżnieniu do niektórych Koryfeuszy nauki, którzy zdawali się nie zauważać, że coś inteligentnego może napisać czy powiedzieć także ktoś dużo młodszy, Sokolewicz to zauważał i doceniał. Nawiązywał do takich wypowiedzi i to mu pozostało do końca. W pisanych przez Niego pracach, w częściach prestiżowego komentarza do Konstytucji pod redakcją L. Garlickiego roi się od powołań prac młodszych Koleżanek i Kolegów, afirmatywnych a gdy trzeba także polemicznych. Lubił towarzystwo młodych, $\mathrm{z}$ wieloma młodymi adeptami sztuki prawa konstytucyjnego był «per ty», nie stwarzał sztucznych barier. Pamiętam własny szok, gdy w 1997 r. podczas kolacji wydanej z okazji organizacji kolejnego zjazdu Katedr Prawa Konstytucyjnego w Ciechocinku, organizowanego przez moją katedrę, podszedł do mnie z dwoma kieliszkami wódki i zaproponował «bruderszaft». Nie chciałem wierzyć, że zaszczyt 
taki uczynił mi sam Wielki Sokolewicz. Od tego czasu nasze kontakty były częstsze i nie były to tylko zdawkowe życzenia czy gratulacje wzajemnie pisywane do siebie. Była to też wymiana publikacji z wzmianką zawsze budzącą u mnie radość gdy ktoś znany i uznany nie tylko zdawkowo dziękuje za cenną, interesującą, inspirującą czy po prostu ciekawą publikację. Podejmowałem na prośbę Wojtka w Toruniu Jego włoskich przyjaciół jak np. swego czasu znakomitego konstytucjonalistę z Perugii profesora Mauro Volpiego. Wojtek miał specyficzny charakter pisma, delikatny jakby nieco kobiecy, lekko węzełkowy nawet, stawiał literki drobne, staranne i zaokrąglone, w jakiś szczególny sposób i tylko Jemu właściwy łączone. Zawsze gdy nadchodził od Niego list bez wskazania adresata na odwrocie koperty, na przysłowiowe sto procent przed jego otwarciem wiedziałem, że to od Wojtka. Widziałem Wojtka ostatni raz i rozmawiałem z Nim na zjeździe w Józefowie pod Warszawą w ubiegłym roku. Był jakiś przygaszony, nieco chudszy niż zwykle dotąd. Takie miałem wrażenie. To nie był ten sam Sokolewicz zawsze ruchliwy, głośny, rzucający się wprost w oczy. Usiadł w pierwszym rzędzie wielkiej sali naszych obrad i przez dłuższą chwilę nie wstawał z krzesła. Ożywił się gdy podszedłem do Niego prosząc o przyjęcie mojej nowej, nietypowej jak na konstytucjonalistę książki o historii Papieskiej Gwardii Szwajcarskiej, i książki mojej córki Kasi. Wspomniał o książce otrzymanej niegdyś od mojego Mistrza, Profesora Wacława Szyszkowskiego na temat historii Wenecji komplementując mnie, że idę śladami Szyszkowskiego, i że to wielki komfort móc napisać coś, czego nie pisze się ani na czas, ani na stopień i dodatkowo pogratulował mi dzieła córki i jej samej. Nie muszę dodawać jak w takiej chwili ciepło robi się na sercu dumnemu z dziecięcia ojcu.

W listopadzie 2011 r. otrzymałem zaproszenie ze Szkoły Koźmińskiego w Warszawie do wzięcia udziału w uroczystości 80-lecia urodzin Profesora Sokolewicza zaplanowanej bodaj na 5 grudnia. Niestety z uwagi na liczne i poważne pod koniec roku komplikacje zdrowotne w rodzinie nie mogłem w tej uroczystości uczestniczyć. Przyznaję, że w nawale moich spraw codziennych, ten piąty grudnia mi umknął, chociaż przygotowałem list gratulacyjny do Wojtka wyjaśniający powody mojej nieobecności, ale wetknąłem go widocznie pod stertę papierzysk na biurku i dopiero ze wstydem odkryłem ten list podczas porządkowania biurka z początkiem semestru letniego, okazało się na zaledwie 2-3 tygodnie przed śmiercią Wojtka. Nie zmieniałem już w nim nic, nawet daty. Dodałem jedynie świeżo wydaną własną 
książkę i w skromnym rewanżu za otrzymane ostatnio dwie prace Wojtka (w tym za księgę jubileuszową z grudnia) wysłałem korespondencję do Warszawy na adres Królowej Marysieńki. Nie wiedziałem, że Wojtek już nie zdąży mi tym razem odpowiedzieć. Zachowam Go w ciepłych wspomnieniach”.

\section{Wspomnienie Profesor Ewy Gdulewicz}

„Profesor Wojciech Sokolewicz nie należał do grona Recenzentów w żadnym $\mathrm{z}$ moich przewodów naukowych a mimo tego jestem $\mathrm{w}$ posiadaniu recenzji mojego doktoratu Jego pióra. Pamiętam, że już po obronie, chyba na Zjeździe Katedr i Zakładów Prawa Konstytucyjnego rozmawialiśmy o mojej pracy i wówczas Profesor, jak zwykle zainteresowany rozwojem młodej kadry naukowej, powiedział, że chętnie by się z nią zapoznał. Wysłałam egzemplarz i po krótkim czasie otrzymałam kilkustronicową, wnikliwą i życzliwą recenzję, zakończoną sugestią podjęcia próby przygotowania pracy do druku. Jak się jednak okazało, rozważania o konstytucji z 1935 roku nie mieściły się wówczas «w profilu» żadnego wydawnictwa. Nieopublikowana recenzja niewydanej książki to nie tylko ciekawostka, ale i cenny dla mnie dowód przyjaźni Wojtka”.

\section{Wspomnienie Profesora Marka Zubika}

„Poznawanie przeze mnie Profesora Sokolewicza było, można tak rzec, wieloetapowe. Początkowo miało to charakter odpersonalizowany. Poznawałem bowiem Jego twórczość naukową. Potem miałem zaszczyt i możliwość poznawać Go osobiście podczas zjazdów katedr, seminariów naukowych, lub spotkań w Trybunale Konstytucyjnym.

Zapamiętam Profesora Wojciecha Sokolewicza jako niezwykle skrupulatnego badacza. Zawsze imponował mi lekkością pióra, rzetelnością twórczości oraz zarówno wnikliwością stawianych tez, jak i krytycyzmem dla zastanych ustaleń nauki prawa w kwestiach, którymi się zajmował. Z racji moich własnych zainteresowań naukowych, w sposób szczególny zapamiętam jednak czas, $\mathrm{z}$ racji moich własnych zainteresowań naukowych, w którym kiedy komentował rozdział X Konstytucji z 1997 r. w wielotomowym 
dziele wydanym przez Wydawnictwo Sejmowe. Powstawanie tego komentarza było dla mnie okazją do częstej, osobistej wymiany poglądów z Profesorem na tematy rzadko poruszane w literaturze prawa konstytucyjnego, dotyczące finansów publicznych. Jeszcze długo dzieło to pozostanie dla mnie bardzo inspirujące w tym zakresie.

W pracy naukowej nigdy nie spotkała mnie ze strony Profesora jakakolwiek nieżyczliwość. Był zawsze rzeczowy, szczery i bezpośredni. W rozmowie czy wymianie myśli w ramach twórczości naukowej nigdy nie dał mi odczuć jakiejkolwiek bariery, wynikającej chociażby z różnicy wieku. Nawet gdy nie podzielał mego poglądu na dany temat, Jego argumenty pozostawały zawsze wyłącznie merytoryczne. Potrafił stworzyć atmosferę partnerskiej rozmowy, choć oczywiste było, że stoi za nim niezaprzeczalnie większy autorytet, a Jego doświadczenie i dorobek są o wiele bogatsze. Ta szlachetna i szczególnie rzadka cecha ujawniająca się w sferze zawodowej współgrała z Jego otwartością i umiejętnością czerpania prawdziwej radości z życia.

Zapamiętam również Wojciecha Sokolewicza jako wnikliwego, lecz jednocześnie życzliwego recenzenta, który, jak sam podkreślał, nie zwykł nikomu robić «laurek». Umiał jednoznacznie wskazać zarówno słabe strony, jak i pozytywnie ocenić zalety recenzowanych wniosków. Nie wykorzystywał swego, skądinąd wybitnego, kunsztu języka pisanego aby zasłonić cokolwiek ważnego dla należytego przeprowadzenia postępowań, do udziału w których był powołany. Profesor Sokolewicz był recenzentem także mojego dorobku naukowego w przewodzie habilitacyjnym oraz w postępowaniu o nadanie tytułu naukowego. Recenzję w tym drugim przewodzie nadesłał na niewiele ponad miesiąc przed swoją śmiercią.

Wojtku, wszystkie te sprawy - zarówno wspomniane tu, jak i te niewypowiedziane - pozostaną na zawsze w mojej wdzięcznej pamięci!”.

\section{Wspomnienie Profesor Haliny Zięby-Załuckiej}

„Czas, wydaje się, że go jeszcze ciągle mamy, że jeszcze zdążymy. Gdybym wiedziała, że to będzie moje ostatnie spotkanie z prof. Wojciechem Sokolewiczem, umiałabym je zaplanować i wykorzystać na dłuższą rozmowę. Był majowy wieczór 2011r., kolacja konferencyjna w hotelu Gromada w Warszawie u prof. J. Jaskierni, a ja miałam ten zaszczyt, że jedliśmy kolację przy jed- 
nym stole. Pan Profesor jak zawsze pogodny, mimo kłopotów zdrowotnych. Kiedy pozwoliłam sobie zaprosić Profesora na konferencję do Rzeszowa na kwiecień 2012 r., odżyły wspomnienia o Podkarpaciu. Pan Prof. był w Polańczyku na organizowanym przeze mnie Zjeździe Katedr, był w Baranowie Sandomierskim na mojej konferencji 10 lat Konstytucji RP. Nie szczędził organizatorce ciepłych uwag, był przecież zawsze aktywnym uczestnikiem zarówno części naukowej, jak i relaksującej. Cieszył Go widok młodych, zdolnych, chłonął atmosferę Bieszczad i sandomierskiego zamku i obiecał, że stawi się w Rzeszowie w kwietniu.

Nie zdążył... Żegnam więc znakomitego prawnika, którego dzieła były niejednokrotnie inspiracją dla mojej pracy naukowej i godzę się z nieuchronnością przemijania”.

\section{Wspomnienie Profesora Mariana Grzybowskiego}

„Wojtek Sokolewicz był nie tylko wybitnym konstytucjonalistą oraz przenikliwym (i krytycznym) obserwatorem realiów ustrojowych. Był człowiekiem obdarzonym wspaniałym poczuciem inteligentnego humoru zespolonego ze swoistym, Jemu tylko właściwym rodzajem sarkazmu. Zaś w rzeczywistości - niezawodnie i bezinteresownie uczynnym Kolegą i Przyjacielem, wiernym i wytrwałym w przyjaźniach. Dla ilustracji - dwa wspomnienia.

1. Pod koniec lat 70. mój Mistrz, Profesor Witold Zakrzewski opublikował swoje opus magnum: Zakres przedmiotowy i formy działalności prawotwórczej (Wydawnictwo Prawnicze, Warszawa 1979, ss. 289). Dzieło obszerne, pogłębione i zwracające uwagę. I jak w takich przypadkach bywa, nie zawsze łatwe w czytelniczym odbiorze. Recenzował je Wojciech Sokolewicz. Do dziś, po latach pamiętam taką frazę: «nie wiem, czy wszystko zrozumiałem, co chciał przekazać Autor. Ale winy za to nie przypisuje wyłącznie sobie».

Pod koniec lat osiemdziesiątych Autor tak «skwitowanej» pracy, Profesor Zakrzewski, doznał wylewu i po dłuższej rekonwalescencji powrócił z Warszawy (gdzie w latach 1981-1985 i 1985-1989 «posłował» do Sejmu) do rodzinnego Krakowa. Nie zdarzyło się, by Wojtek Sokolewicz, będąc «pod Wawelem», nie odwiedził Profesora w Jego mieszkaniu przy Alei Pokoju. I by zjawił się bez kwiatów dla Małżonki Profesora. Ot, cały Wojtek! 
2. W 2009 r. Wydział Prawa Uniwersytetu w Białymstoku czcił księgą Prawo, parlament i egzekutywa pamięć zmarłego w 1989 r., pierwszego z wykładowców prawa konstytucyjnego Filii UW w Białymstoku, Profesora Jerzego Stembrowicza. Profesor Sokolewicz nie tylko terminowo przekazał do Ksieggi erydycyjne studium Funkcje sił zbrojnych. Konstytucja i rzeczywistość, nawiązujące znakomicie do prac J. Stemmbrowicza o stanach nadzwyczajnych. Nie szczędząc czasu i wysiłku, wziął udział w białostockich uroczystościach, ciepło i z humorem wspominając Profesora. Pozostał z gospodarzami uroczystości do samego końca, do opuszczenia budynku Wydziału przez uczestniczącą w konferencji Rodzinę Profesora. Jak nakazywała pamięć i dobry, stary uniwersytecki obyczaj”.

\section{Wspomnienie Profesora Ryszarda Chruściaka}

„W czasach gdy rozpoczynałem pracę naukową, czyli w drugiej połowie lat siedemdziesiątych możliwości bezpośredniego poznania, czy nawiązania znajomości przez młodego pracownika nauki z czołowym przedstawicielem nauki były bardzo ograniczone. Zasadą było to, iż najpierw następowało swego rodzaju poznanie pośrednie, a wiec poprzez publikacje naukowe. Tak też było w przypadku mojego «poznania» Profesora Wojciecha Sokolewicza. Stało się to za pośrednictwem przede wszystkim Jego książki dotyczącej zmian konstytucyjnych wprowadzonych w 1976 r. (Konstytucja PRL po zmianach z 1976 r. PWN. Warszawa 1978). Była to publikacja bardzo oczekiwana szczególnie przez młodych pracowników naukowych. Poszukiwali oni bowiem odpowiedzi na problemy wynikające zwłaszcza $z$ istotnych kontrowersji politycznych i prawnych towarzyszących tej nowelizacji.

Okazją do bezpośrednich spotkań są oczywiście konferencje naukowe. W przypadku środowiska naukowego prawa konstytucyjnego można nawet mówić o szczególnej ale i bardzo pozytywnej sytuacji znajdującej wyraz w corocznych zjazdach katedr i zakładów prawa konstytucyjnego. Właśnie te zjazdy dały mi pierwszą okazję obserwacji debat naukowych $\mathrm{z}$ udziałem Profesora Wojciecha Sokolewicza cieszącego się prestiżem pracownika naukowego Instytutu Nauk Prawnych Polskiej Akademii Nauk. Byłem wówczas także pod wrażeniem prezentowanej przez Niego jasność i komunikatywność przekazu. Nie bez znaczenia było również dostojeństwo wyni- 
kające z samej fizycznej sylwetki Profesora. Okoliczności te mogły wskazywać, iż chodzi o Uczonego mającego skłonność do traktowania innych osób z dystansem. Rzeczywistość całkowicie zaprzeczyła tym przypuszczeniom. Dzięki kolejnym zjazdom katedr i zakładów prawa konstytucyjnego miałem okazję przekonać się, że Profesor Wojciech Sokolewicz to człowiek nie mający nawyku budowania nadmiernych barier w kontaktach z innymi ludźmi. Okazało się także, że Jest człowiekiem bardzo towarzyskim nie stroniącym od udziału w ogniskach czy grupowych śpiewach towarzyszących bardziej «turystycznym» częściom konferencji naukowych. W kolejnych latach zostałem zaszczycony tym, że mogłem nazywać Go Wojciechem. Bardziej częste kontakty były okazją do wielu rozmów nie tylko na tematy naukowe.

$\mathrm{Na}$ kolejnych etapach mojej drogi naukowej Profesor Wojciech był obecny w bardzo znaczących rolach przede wszystkim jako recenzent rozprawy habilitacyjnej, a przed niespełna rokiem jako autor opinii naukowej w procedurze ubiegania się o stanowisko profesora nadzwyczajnego w Uniwersytecie Warszawskim. Był krytyczny, ale zarazem życzliwy i bez cienia złośliwości.

Jego odejście jest więc nie tylko śmiercią wybitnego Uczonego, ale dla mnie także stratą mądrego, życzliwego starszego Kolegi i Przyjaciela”.

\section{Wspomnienie Profesora Tadeusza Smolińskiego}

„Zmarł jeden z największych polskich prawników konstytucjonalistów. Jeden z największych nie tylko intelektem, ale także postawą - figurą i tubalnym głosem Profesor Wojciech Sokolewicz nie mówił On głosił swoje poglądy. Jeżeli nawet nie każdy z Jego poglądów nie każdego przekonywał to w każdym razie zmuszał do poważnego zastanowienia się. On nie chodził, On przemieszczał swoją dostojną poważne j wagi i miary figurę.

Profesor Wojciech Sokolewicz (miałem zaszczyt i szczęście, że dla mnie był to Wojtek) był z pewnością w pełni człowiekiem renesansu. Dla Niego nic co ludzkie nie było Mu obce. Był prawdziwym wielkim człowiekiem nauki - o czym świadczą Jego dzieła, ale umiał też podziwiać piękno kobiet, czy smak prawdziwie dobrych trunków - co mogą potwierdzić Jemu współcześni. 
O jego wielkim wymiarze naukowym świadczą nie tylko publikowane prace, ale także pełne ładunku intelektualnego wystąpienia na różnego rodzaju zjazdach czy sympozjach naukowych. Ja (z pewnością jak wielu innych) pamiętam Wojtka z naszych corocznych zjazdów katedr. Był nie tylko luminarzem nauki w trakcie oficjalnych wystąpień, był też «duszą towarzystwa» na wieczorno-nocnych spotkaniach przyjaciół.

W ramach przygotowań do otwarcia dorocznej sesji katedr, organizowanej w Międzyzdrojach przez Katedrę Prawa Konstytucyjnego Uniwersytetu Szczecińskiego, prof. Andrzej Bałaban zaproponował mi bym prowadził pierwsze posiedzenie. Stwierdziłem wtedy, że fawor ten bardziej należ się profesorowi Sokolewiczowi. Dlatego też zwróciłem się do Wojtka, by przejął prowadzenie. Wtedy usłyszałem «... wiesz, nie czuję się najlepiej. Przy innej okazji, gdy Ty będziesz się czuł gorzej, to zastąpię Ciebie».

Wojtusiu - stwierdzam to z żalem... nie dotrzymałeś słowa (być może pierwszy i jedyny raz).

P.S. Podobno, żeby być szczęśliwym wystarczy mieć uznanie współczesnych i spokojny sen. Uznanie u ludzi miałeś i masz... spokojny sen też”.

\section{Wspomnienie Profesora Pawła Sarneckiego}

„Postać ś.p. profesora Wojciecha Sokolewicza zaznaczyła się w sposób nader szczególny w mojej działalności naukowej na niwie prawa konstytucyjnego. Otóż na samym jej początku mój kierownik naukowy, profesor Witold Zakrzewski zasugerował mi opracowanie recenzji z pierwszej samodzielnej pozycji książkowej W. Sokolewicza Rząd a prezydia rad narodowych. Recenzja ta ukazała się rzeczywiście w «Państwie i Prawie», tematycznie mieszcząc się $\mathrm{w}$ ustalonym mi przez promotora obszarze badań nad rozprawą doktorską. W ten sposób praca doktorska prof. W. Sokolewicza stała się przedmiotem mej pierwszej publikacji naukowej. Podobnie zresztą stało się z następną monografią prof. W. Sokolewicza, również poświęconą problematyce organizacji ówczesnej władzy terenowej (Przedstawicielstwo i administracja $w$ systemie rad narodowych), którą zrecenzowałem na łamach «Gospodarki i administracji terenowej». Na uważnym przestudiowaniu tych dwu monografii wiele skorzystałem w swoich pracach nad doktoratem, a osobiście dałem się poznać ich Autorowi który, jak pamiętam, żartobliwie (czy- 
li w charakterystyczny dla siebie sposób) ale z uznaniem skomentował moje próby podążania śladem Jego twórczości (zrewanżował mi się też z dużym naddatkiem, składając znacznie później bardzo interesujące opracowanie do mej Księgi Pamiątkowej). Miałem też przyjemność występować z Nim razem w grupie laureatów konkursu «Państwa i Prawa». W «poważniejszej» twórczości naukowej drogi nasze krzyżowały się następnie kilkakrotnie przy okazji recenzowania tych samych prac doktorskich lub habilitacyjnych naszych młodszych Koleżanek i Kolegów, w różnych ośrodkach uniwersyteckich. Jego recenzje cechowały się zawsze wysoką kompetencją merytoryczną, lecz również odczuwalną życzliwością wobec wszystkich autorów recenzowanych rozpraw.

W latach siedemdziesiątych i osiemdziesiątych ubiegłego wieku, podobnie jak całe środowisko konstytucjonalistów polskich, śledziłem z ogromnym uznaniem rozwój twórczości naukowej prof. Wojciecha Sokolewicza. Zaskakiwał nas wszystkich zwłaszcza wkraczaniem na coraz to nowe obszary badawcze, w tym choćby poprzez liczne opracowania dotyczące instytucji i myśli ustrojowej USA a także innych państw, choć, co warto podkreślić, ze szczególnym uwzględnieniem państw naszego regionu. Nie odrywał się jednak od aktualnych kwestii ustrojowych PRL, jakby chcąc dać do zrozumienia iż winniśmy, wbrew wszelkim zakrętom politycznym («jak się nie ma co się lubi...»), w sposób pragmatyczny bazować na tych pewnych osiągnięciach jakie udało się już wypracować w Polsce, celem wyciągnięcia z nich takich konsekwencji, które niekoniecznie przyświecały aktualnym czynnikom rządzącym. Te konsekwencje to po prostu możliwy rozwój wszelkich przejawów ludowładztwa i praworządności. Przynajmniej tak było z moim odczytywaniem prac naukowych Profesora. Dość np. wskazać, że w książce o zmianach Konstytucji PRL z roku 1976 nie komentował bliżej nowych przepisów o kierunkach polityki zagranicznej PRL, ale już szeroko kompetencję Rady Państwa do «czuwania nad zgodnością prawa z Konstytucją». Z tytułu mych zainteresowań naukowych śledziłem zaś pilnie Jego rzeczowe publikacje na zapomnianych już dzisiaj całkowicie łamach «Problemów Rad Narodowych», których był współtwórcą. Dlatego, o czym jestem przekonany, prof. Wojciech Sokolewicz nie musiał odcinać się od Swego dorobku, gdy nastały czasy III Rzeczpospolitej. Czuł się też powołany - kto wie, czy nie jako pierwszy - do komentowania nowych instytucji ustrojowych w publikacjach o Polsce jako demokratycznym państwie prawnym (1990), 
o konstytucyjnej regulacji partii politycznych (1991), Prezydencie RP, Trybunale Konstytucyjnym (nie przewidując chyba, że przyjdzie Mu samemu zmierzyć się później z trudami pracy sędziego TK) i innych zmianach konstytucyjnych. Na tym polu w sposób szczególny wykazał się jako niezmiernie wnikliwy komentator w dwu komentarzach konstytucyjnych - do Małej Konstytucji i do Konstytucji aktualnej. Zajmował głos wobec bieżących zagadnień z praktyki ustrojowej jako pracownik Biura Studiów i Ekspertyz Sejmu. Dobrze się stało, że te rozproszone wypowiedzi, wyszłe spod Jego pióra, zostały ostatnio zintegrowane w specjalnym tomie jubileuszowym. Jako uczestnik licznych konferencji głos Profesora był zawsze uważnie wysłuchiwany a jako często zapraszany uczestnik zagranicznych sympozjów skutecznie propagował tam osiągnięcia polskiej myśli konstytucyjnej. Dużym wydarzeniem na niwie nauki polskiego prawa konstytucyjnego okazała się również Księga Pamiątkowa, wręczona Mu w roku 2002 w imieniu naszego środowiska. Poczytuję sobie za zaszczyt fakt, że zostałem zaproszony do współudziału w jej powstaniu.

Profesor Wojciech Sokolewicz był przy tym, przy wszystkich swoich osiągnięciach, wręcz zaprzeczeniem gabinetowego naukowca. Będziemy Go pamiętać co najmniej w równym stopniu tak z uwagi na wybitne naukowe osiągnięcia jak i ze względu na bezpośredniość w relacjach z kolegami, skrzące się humorem wypowiedzi na bardziej czy mniej oficjalnych spotkaniach a przede wszystkim za chętnie przyjmowaną rolę «duszy towarzystwa» na naszych corocznych Zjazdach Katedr. W roli tej wytrwale i z powodzeniem przewodził zawsze do samego końca. Martwiliśmy się wszyscy, gdy kilka lat temu doszły nas wieści o poważnym ataku choroby, cieszyliśmy się gdy kryzys tym wywołany udało Mu się przezwyciężyć. Dziś wszyscy, a szczególnie ci, którzy zainspirowani zostali choć trochę Jego przemyśleniami, za to wszystko Mu dziękujemy".

\section{Wspomnienie Profesora Kazimierza Działochy}

„Wiadomość o śmierci Profesora Wojciecha Sokolewicza była dla jego przyjaciół i kolegów ze środowiska konstytucjonalistów zupełnym zaskoczeniem. Jeszcze w czerwcu ubiegłego roku podziwialiśmy go jak sprawnie i błyskotli- 
wie przewodniczył posiedzeniu na kolejnej, 53 - ciej konferencji katedr i zakładów prawa konstytucyjnego.

Śmierć Wojciecha Sokolewicza każdemu z nas przywodzi na pamięć Jego sylwetkę osobową i naukową, dzieło i dorobek naukowy, który zostawił po sobie. Każdy z nas widzi i ocenia je na podstawie własnych wspomnień, kontaktów osobistych i wspólnych z Profesorem przedsięwzięć naukowych. Ja poznałem osobiście profesora Wojciecha Sokolewicza stosunkowo późno, bo dopiero w 1970 r. przy okazji ważnej dla nas obu uroczystości wręczenia nam nagród w dorocznym konkursie «Państwa i Prawa» na najlepsze prace habilitacyjne. Wojciech otrzymał pierwszą nagrodę za swoją rozprawę na temat przedstawicielstwa i administracji w systemie rad narodowych; druga, za pracę prawnoporównawczą o instytucji dekretu z mocą ustawy przypadła mnie. Nie konkurowaliśmy ze sobą w późniejszych zmaganiach z problematyka prawa konstytucyjnego, lecz - co było zrozumiałe $\mathrm{z}$ racji pozostawania w ramach tej samej dyscypliny nauki prawa - uczestniczyliśmy wspólnie w wielu przedsięwzięciach naukowych, w szczególności w dorocznych sesjach katedr i zakładów prawa konstytucyjnego, konferencjach i zjazdach Polskiego Towarzystwa Prawa Konstytucyjnego. Wojciech Sokolewicz był powszechnie oczekiwaną osobą na tych zgromadzeniach, znanym ze swoich polemik naukowych oraz przysłowiową duszą spotkań towarzyskich. Przyszło nam też pracować razem nad realizacją wspólnych projektów naukowych w okresie prac nad teoretycznymi założeniami przyszłej Konstytucji RP, a po jej uchwaleniu nad wielotomowym komentarzu do niej. Wojciech Sokolewicz był sumiennym i rzetelnym, chociaż czasem niespiesznym uczestnikiem tych prac. Jego autorski wkład w publikacje, które były rezultatem tych badań zaważył istotnie na ich naukowym powodzeniu.

Nie jest celem tej notatki ocena dorobku naukowego Profesora Wojciecha Sokolewicza. Doczeka się on z pewnością godnej i sprawiedliwej oceny. Pragnę jednak już w tym miejscu stwierdzić, że jest to dorobek wyjątkowo obszerny, oryginalny i cenny, nie mający być może równego sobie w naszej dyscyplinie prawa w okresie ostatnich 30 lat. Charakteryzuje ten dorobek wyjątkowa rozległość tematyczna, wychodząca poza tradycyjne granice prawa konstytucyjnego, a metodologicznie przekraczająca klasyczne sposoby interpretacji instytucji życia prawnego. W parze $\mathrm{z}$ tym idzie umiejętna obserwacja przemian, jakie dokonywały się za życia Profesora w obrębie ustrojów państwowych naszej części Europy. Cały Jego dorobek cechuje także 
zrozumienie potrzeby bliskiego związku nauki prawa z praktyką i służenia jej. Tej drugiej służył wyjątkowo intensywnie jako ekspert naczelnych władz państwa.

Ostatni nasz kontakt miał związek z uroczystością jubileuszu 80-lecia Profesora. Nie mogłem wziąć udziału w tej uroczystości. Wymieniliśmy tylko listownie nasze uczucia i doświadczenia właściwe rówieśnikom. Otrzymałem też Jego ostatnią ważną publikację «Prasa i Konstytucja» wydaną w 2011 r., dowód tego, że nie ustawał w intensywnej pracy naukowej w ostatnim okresie swojego życia. Liczyłem na osobistą rozmowę z Wojciechem przy najbliższej okazji pobytu w Warszawie, lecz nie było dane nam się spotkać”.

\section{Wspomnienie Profesora Jana Skupińskiego}

„Profesora Sokolewicza poznałem pół wieku temu. Podjął wtedy pracę w Instytucie Nauk Prawnych PAN, w którym ja byłem doktorantem. Znałem go bardzo dobrze. Był nie tylko moim długoletnim «kolegą z pracy», ale łączyły nas też osobiste więzy koleżeńskie i przyjacielskie. Był wybijającą się indywidualnością. Nie tylko jako uczony, ale jako człowiek stale ciekawy świata i ludzi. Miał świetny kontakt z młodzieżą naukową. Najpierw był ich starszym kolegą, potem nauczycielem i mentorem. To ostatnie było wynikiem poważania i autorytetem jakim się wśród nich cieszył. Ale nie było to mentorstwo napuszone i koturnowe, lecz przyjacielskie i partnerskie. Zresztą człowiek o jego poczuciu humoru i tak pełen życzliwego zainteresowania tym co go otacza nie czułby się dobrze gdyby lokowano go na jakimś piedestale. Ta młodzież to kolejni doktoranci, asystenci z Instytutu i uczelni w której wykładał. Nie tylko zresztą. Wielu z nich pochodziło z innych ośrodków, także pozawarszawskich. On potrafił gromadzić wokół siebie młodych, a oni zaś bardzo chętnie z tego korzystali. Znane były jego celne i dowcipne bon moty, które młodsi chętnie powtarzali, z czasem uznając je za własne.

Był wnikliwym obserwatorem rzeczywistości oglądanej z należytym dystansem. Miał mocno zakorzenione poczucie realizmu i w razie potrzeby potrafił być pryncypialny. Ale tak mocno stąpając po ziemi, miał jednocześnie naturę sentymentalną i wyrażało się to nie tylko w jego zachwycie, z jakim słuchał starych romansów. Jego bogate płyto-, a potem, taśmoteka były ich pełne. Z tym że jego zbiór literatury fachowej i naukowe archiwum były jesz- 
cze bardziej imponujące. W tym wszystkim chyba jednak przeważała jego romantyczna natura. Ostatnia Niedziela, która, obok Pożegnania, zabrzmiała nad Jego grobem była tym, co chciał usłyszeć".

\section{Wspomnienie Profesora Ryszarda Małajnego}

„Jakkolwiek formalnie miałem tylko jednego mistrza - tj. męża, który był moim opiekunem naukowym - to w istocie miałem ich kilku. Idzie mi bowiem o uczonych, którzy wywarli na mnie największy wpływ. A największym z wielkich był właśnie Profesor Wojciech Sokolewicz. Uważam Go za najwybitniejszego polskiego konstytucjonalistę XX w.

Dlaczego? Bo miał dwie cechy, które nieczęsto idą ze sobą w parze: wielki umysł, ale też wielkie serce. Miałem okazję poznać te cechy bardzo dobrze, ponieważ Profesor był moim «urzędowym» recenzentem - od doktoratu aż po profesurę zwyczajną; nie liczę przy tym różnych «rzeczy po drodze». Okazał się recenzentem krytycznym, ale ogromnie życzliwym, a przy tym jakże bezpośrednim i skromnym człowiekiem. Staram się Go pod tym względem - pewnie nieudolnie - naśladować.

Z sentymentem wspominam moje pierwsze z nim spotkanie, do którego doszło późną wiosną 1978 r. w INP PAN. Czekałem na Niego w Jego pokoju, po chwili wchodzi, przedstawia się i powiada: «Ja do Pana zaraz wrócę, na razie niech Pan pilnuje mojej teczki!» i wyszedł. Po chwili do pokoju weszła dr Romana Sadurska i zobaczywszy mnie, zapytała co tu robię. Odpowiedziałem, że pilnuję teczki Pana Profesora Sokolewicza. Na to odpowiedziała z lekkim przekąsem, żebym pilnował dalej i pokój opuściła.

Profesor znał doskonale nie tylko moje zainteresowania amerykanistyczne, ale i prawdziwą fascynację ustrojem USA. Z tą fascynacją w ustroju «sprawiedliwości społecznej» lepiej było się nie obnosić. Kiedy więc w 1979 r. powiedziałem $\mathrm{Mu}$, że wiozę artykuł do «PiP» i mam wątpliwości czy pewien akapit Redakcja «puści» z powodów politycznych - było tam m.in. o zasłużonej dumie narodu amerykańskiego ze swych instytucji ustrojowych - odparł tym swoim tubalnym głosem: «Niech Pan mi to pokaże, bo jak już Pan ma wątpliwości, to wyobrażam sobie...». Przeczytał i rzekł: «Ja Pana bardzo przepraszam» i skreślił mi półstronicowy akapit. Cóż, chronił mnie przede mną samym - takie to były czasy. 
Tak samo czynił w recenzji wydawniczej mojej habilitacji (Doktryna podziału władzy „Ojców Konstytucji” USA, 1985), kiedy to - krytykując pośrednio komunistyczną ideologię walki klas, napisałem, że ważniejsze wydarzenia ustrojowe rzadko dają się wytłumaczyć wskazaniem na jedną lub dwie przyczyny. Profesor napisał wówczas, że «przekornie zanegowałem ideologiczne wskazania marksizmu». Cóż, przekory nigdy mi nie brakowało - widać taka już moja uroda. Brakowało mi natomiast intelektualnego szlifu; jeśli go mam, to zawdzięczam go przede wszystkim mojemu Mistrzowi”.

\section{Wspomnienie Profesora Dariusza Góreckiego}

„Na wstępie pragnę zaznaczyć, że trudno mi jest pisać o Profesorze Wojciechu Sokolewiczu jako o kimś, którego już nie ma... Profesora poznałem na którymś ze Zjazdów Katedr i Zakładów Prawa Konstytucyjnego. Bodajże było to w Ślesinie w 1979 roku. Zawsze imponował mi swoją erudycją. W dyskusjach zabierał głos w sposób niezwykle kompetentny, puentując swe wystąpienia celnymi spostrzeżeniami. Jako urodzony gawędziarz był osobą towarzyską, mającą doskonały kontakt z młodzieżą. Dorobek naukowy Profesora jest niezwykle bogaty (ponad 500 pozycji). Nie jest to jednak miejsce ani na jego ocenę, ani na prezentację bogatej kariery zawodowej Profesora. Jestem wdzięczny Profesorowi, że nie odmówił mej prośbie i zgodził się wystąpić z referatem na zorganizowanym przez łódzki ośrodek Zjeździe Katedr w Spale w 2003 roku. Referat pt. Krajowa Rada Radiofonii i Telewizji jako problem prawnokonstytucyjny - jak każde wystąpienie Profesora - spotkał się z żywym zainteresowaniem słuchaczy. Odejście Profesora Wojciecha Sokolewicza jest niepowetowaną stratą dla nauki polskiej, zwłaszcza dla środowiska polskich konstytucjonalistów".

\section{Wspomnienie Profesora Jerzego Jaskierni}

„Choć śmierć jest zjawiskiem nieuniknionym, to w przypadku Profesora Wojciecha Sokolewicza niosła z sobą ogromny wstrząs dla Jego przyjaciół. Niezwykła osobowość Prof. Sokolewicza, jego żywotność, humor, koleżeńskość powodowały, że z trudem przychodziło nam pogodzić się z myślą, że 
Jego już nie ma wśród nas. Przez lata zmagał się dzielnie z chorobami i wydawało się, że będzie mógł jeszcze długo żyć - zwłaszcza, że do ostatniej chwili był czynny zarówno na niwie dydaktycznej, jak i naukowej.

Wojciecha Sokolewicza znałem od 40 lat, a więc od początku mej kariery naukowej. Spotykaliśmy się na zjazdach prawa konstytucyjnego, ale szczególnie nas zbliżyła współpraca $\mathrm{w}$ ramach Zespołu badań nad instytucjami i doktrynami polityczno-prawnymi w USA, prowadzonego przez Niego w latach siedemdziesiątych w Instytucie Państwa i Prawa PAN w Warszawie. Efektem tych badań były dwa tomy, mające prekursorski charakter w polskiej amerykanistyce ustrojowej: Instytucje $i$ doktryny prawno-polityczne Stanów Zjednoczonych Ameryki oraz Instytucje polityczno-prawne Stanów Zjednoczonych Ameryki.

W mojej życzliwej pamięci pozostanie fakt, że prof. Sokolewicz był recenzentem mej pracy doktorskiej Prawno-ustrojowa pozycja stanów w USA i zagadnienie ich roli $w$ realizacji zadań państwa, napisanej pod kierunkiem prof. Witolda Zakrzewskiego i obronionej na Uniwersytecie Jagiellońskim w 1977 r. Korzystałem z jego uwag przy przygotowywaniu pracy habilitacyjnej pt. Zasada równości w prawie wyborczym USA (przewód w Instytucie Nauk Prawnych PAN, w którego Radzie Naukowej zasiadał prof. Sokolewicz). To On podsunął mi pomysł na «książkę profesorską», zatytułowaną Zasady demokratycznego państwa prawnego w sejmowym postępowaniu ustawodawczym. To On zapraszał mnie do współpracy naukowej, m.in. redagując tom Bezpieczeństwo w ramach serii «Krytyka prawa», wydawanej przez Kolegium Prawa Akademii Leona Koźmińskiego. To On był aktywnym uczestnikiem organizowanych przez mnie międzynarodowych konferencji naukowych: Szklarska Poręba (2009), Legnica (2010) i Warszawa (2011). Miał przewodniczyć obradom plenarnym podczas kolejnej konferencji w Warszawie, w dniach 22-23 kwietnia 2012 r., ale jej nie doczekał. Mogę więc bez cienia przesady powiedzieć, że prof. Sokolewicz był «dobrym duchem» w całej mej karierze naukowej, za co jestem mu ogromnie wdzięczny.

Zapamiętam Go jako człowieka, który łączył szereg cech jednocześnie: wybitnego konstytucjonalisty, dysponującego niepowtarzalnym, oryginalnym językiem; tytana pracy, który «spalał się» w twórczości naukowej, stale szukając nowych frontów badawczych; świetnego dydaktyka, który stosunkowo późno stał się aktywny na tym polu (początki swej kariery związane były $z$ typem badacza nie obarczonego dydaktyką), ale polubił kontakt 
z młodzieżą i przywiązywał dużą wagę do doskonalenia swego warsztatu dydaktycznego; człowieka zatroskanego o Rzeczpospolitą i mocno przeżywającego wszelkie ustrojowe napięcia i problemy; świetnego kompana biesiad, konesera dobrego wina, świetnego tancerza (może potwierdzić to moja żona, Alicja), tryskającego humorem, ciętymi obserwacjami; wielbiciela wszystkiego co piękne, czułego zwłaszcza na urodę kobiet. Pieszczotliwa ksywa «Ropuch», jaka mu towarzyszyła, bardzo dobrze nawiązywała do Jego osobowości i charakteru. Poczucie humoru dawało znać, gdy nazwał swego psa - «Komuchem».

Nie zapomnę uroczych kolacji w mieszkaniu Państwa Sokolewiczów gdzie, przez lata, z aktywnym udziałem Jego żony, Wandy, doświadczonego legislatora w Biurze Legislacyjnym Kancelarii Sejmu - długimi godzinami rozmawialiśmy o Polsce, o Sejmie, o polityce, o tworzeniu prawa, o różnych paradoksach otaczającej nas rzeczywistości.

Prof. Sokolewicz bardzo wiele wymagał od siebie, ale też od innych; był surowym, a zarazem życzliwym recenzentem. Przez szereg lat był podporą redakcji «Państwa i Prawa», analizując teksty z obszaru prawa konstytucyjnego. Często zwracały się do Niego po ekspertyzy: Kancelaria Sejmu, Kancelaria Senatu i Kancelaria Prezydenta. Słynął bowiem z nieszablonowego spojrzenia na zagadnienia ustrojowe, zadziorności intelektualnej i uczciwości naukowej. Szczególne znaczenie przywiązywał do swego wkładu do Komentarza do Konstytucji Rzeczypospolitej Polskiej pod red. L. Garlickiego. Te trwające przez lata prace absorbowały go w szczególny sposób. Trudno się dziwić, skoro każda jego nota w komentarzu to prawdziwa "perełka» intelektualna, starannie opracowana, erudycyjna, ukazująca jego umiejętność syntetyzowania problemów ustrojowych. Nie sposób też zapomnieć o Jego wkładzie do prac Komisji Konstytucyjnej w latach 1990-1991.

Jego talent analityczny i doskonała znajomość różnych działów prawa dały o sobie w sposób szczególny znać w latach 1984-1992, gdy był członkiem Rady Legislacyjnej przy Prezesie Rady Ministrów. Ukoronowaniem jego kariery był jednak okres lat 1993-1999, gdy pełnił godność sędziego Trybunału Konstytucyjnego. Ta funkcja wywarła istotny wpływ na Jego osobowość. Trybunał stał się Jego «drugim domem», do którego wracał przez lata, by żyć jego atmosferą i problemami.

Był skromnym człowiekiem. Nigdy nie zapomnę, gdy na uroczystości z okazji 70-lecia urodzin, w Sali lustrzanej Pałacu Staszica w Warszawie, mó- 
wił o sobie, że w zasadzie nic ważnego nie napisał, a przecież Jego dorobek naukowy na trwale wszedł do historii polskiego prawa konstytucyjnego.

Gdy patrzyłem na jego aktywność naukową w ostatnich miesiącach, to miałem wrażenie, że walczy z czasem i chce zostawić w swym testamencie naukowym dwa dzieła, które będą stanowiły podsumowanie Jego wysiłków badawczych. Pierwsze zdążył opublikować w postaci książki: Prasa $i$ konstytucja. Drugie, mające dotyczyć sił zbrojnych w Konstytucji RP, nie zostało dokończone.

Szczególnie wymowna jest jednak książka pt. Prawa kobiet we współczesnym świecie, zredagowana przez Wojciecha Sokolewicza i Lenę Kondratiewą-Bryzik. Przywiązywał do tej książki duże znaczenie. Była ona pokłosiem konferencji zorganizowanej pod jego kierownictwem na Akademii Leona Koźmińskiego. Nie mogłem osobiście uczestniczyć w tej konferencji, ale - na prośbę Prof. Sokolewicza - przygotowałem opracowanie o prawach kobiet w systemie aksjologicznym Rady Europy. Cieszył się z ukazania się tej książki, która była też symbolem jego sympatii dla Leny, z którą współpracował od lat. Pozostanie wymownym faktem to, że obaj redaktorzy opuścili doczesny świat tuż po ukazaniu się tej pracy, w odstępie kilku dni. Lena Kondratiewa-Bryzik zginęła w katastrofie kolejowej pod Szczekocinami. Prof. Sokolewicz bardzo przeżył tę śmierć. Być może stres z tym związany przyczynił się do jego śmierci.

Prof. Wojciech Sokolewicz pochowany został na warszawskich Powązkach w dniu 21 marca 2012 r. - w dniu, gdy obchodziłem urodziny. Ta smutna klamra spięła okres naszej znajomości i długoletniej przyjaźni. Odszedł od nas, ale Jego dorobek naukowy i postawa życiowa długo będą jeszcze inspirowały pokolenia polskich konstytucjonalistów.

Cześć Jego pamięci!”

\section{Wspomnienie Profesora Stanisława Bożyka}

„Śmierć Profesora Wojciecha Sokolewicza to ogromna strata dla nauki polskiego prawa konstytucyjnego. Dorobek naukowy Profesora jest imponujący, składa się bowiem z ponad 500 opracowań obejmujących swoim zakresem wszystkie istotne kwestie prawnoustrojowe.

Warsztat badawczy Profesora oraz Jego aktywność naukowa były zawsze doskonałym wzorem dla młodszych kolegów i współpracowników. Wszyscy 
będziemy też pamiętali jego błyskotliwe wystąpienia podczas licznych konferencji naukowych. Profesor był przy tym człowiekiem niezwykle życzliwym, można było zawsze liczyć na Jego pomoc i cenne rady.

Profesora Wojciecha Sokolewicza poznałem przed trzydziestu laty, podczas obrony na UW mojej pracy doktorskiej, której był recenzentem. Już wówczas zaimponował mi swoim eleganckim stylem i klarownością wypowiedzi oraz trafnymi uwagami, jakie czynił w trakcie dyskusji nad tezami rozprawy.

W mojej pamięci pozostaną wspomnienia z licznych spotkań z Profesorem, zarówno przy okazji konferencji i zjazdów naukowych, jak i na gruncie prywatnym. Chcę też dodać, że Profesor zawsze bardzo szybko odpowiadał na moją korespondencję. Listy od Niego będą dla mnie niezwykle cenną pamiątką.

Moje ostatnie spotkanie z Profesorem miało miejsce 5 grudnia ubiegłego roku w Akademii Leona Koźmińskiego podczas uroczystości Jubileuszu osiemdziesięciolecia Jego Urodzin. W krótkiej rozmowie Profesor zachęcał mnie do kontynuacji poważnego projektu badawczego i wspominał o swoich najbliższych planach wydawniczych.

Po raz ostatni rozmawiałem telefonicznie $z$ Profesorem pod koniec lutego o zbliżającym się Zjeździe Katedr Prawa Konstytucyjnego. Pytał mnie m.in. o szczegóły planowanego rejsu statkiem po augustowskich jeziorach. Niestety, Pan Profesor nie popłynie już z nami w ten rejs...”.

\section{Wspomnienie Profesora Krzysztofa Skotnickiego}

„Z Profesorem Wojciechem Sokolewiczem pierwszy raz zetknąłem się w maju 1977 r. podczas Zjazdu Katedr i Zakładów Prawa Konstytucyjnego zorganizowanego w Ustroniu Wielkopolskim przez moją macierzystą Katedrę. Zjazdy oraz krajowe i zagraniczne konferencje naukowe były też chyba jedynymi miejscami naszych licznych od tamtego czasu kolejnych spotkań, nie przypominam sobie bowiem, aby występował w bronionym $\mathrm{w}$ Łodzi przewodzie doktorskim czy habilitacyjnym, nigdy nie byliśmy również recenzentami w tym samym postępowaniu. Szczególnie wdzięczny pozostaję Mu za to, że przyjmował moje zaproszenia na międzynarodowe konferencje odbywające się w 2002 r., 2005 r. i 2008 r. w ramach łódzkich Festiwali 
Dialogu Czterech Kultur. Jego przyjazd zawsze znacznie podnosił ich rangę. W sferze naukowej Profesor Wojciech Sokolewicz to oczywiście wybitny erudyta, do którego prac bez wątpienia będą sięgać kolejne pokolenia konstytucjonalistów. Będą one pozbawione już jednak tego, co jest dane tym, którzy znali Go osobiście, nie poznają bowiem jego otwartości na innych ludzi i serdeczności sprawiających, że zawsze wokół niego było tak wiele osób $\mathrm{w}$ różnym wieku. Taki pozostanie też w mojej pamięci. I mogę jedynie żałować, że spiesząc się zawsze do Łodzi nigdy nie skorzystałem z zaproszeń do odwiedzenia Go w domu, że nie dostanę już od Niego kolejnego listu z życzeniami czy podziękowaniem za przesłany tekst, że nie odbędziemy kolejnej rozmowy telefonicznej. I trudno jest mi pogodzić się z myślą, że nie zobaczę Wojtka w tym roku na Zjeździe Katedr i Zakładów Prawa Konstytucyjnego w Augustowie".

\section{Wspomnienie Profesora Marka Chmaja}

„Wojciech Sokolewicz był bez wątpienia nietuzinkową postacią. Jeden z najznakomitszych konstytucjonalistów, człowiek o niezwykle szerokich horyzontach intelektualnych. Autor znakomitych komentarzy, artykułów i glos, a także bardzo wielu publikacji książkowych. Osoba niezwykle pracowita, zadziwiająca otoczenie swoją witalnością i wytrwałością. Od wielu już lat nie musiał pisać, był przecież profesorem zwyczajnym. Ale dla Wojtka działalność naukowa zawsze była wewnętrznym imperatywem: uważał ją za najlepszy sposób na ćwiczenie umysłu. Dawał przykład młodszym pokoleniom konstytucjonalistów jak należy podchodzić do działalności naukowej.

Jego opinie prawne były niemalże wzorem rozumowania prawniczego i chociaż nie zawsze zgadzałem się z konkluzjami, to jednak zawsze pozostawałem pod ogromnym wrażeniem Jego argumentacji. Potrafił się przekomarzać, spierać, podtrzymywać odmienne interpretacje, ale zawsze czynił to nie z niezwykłą kulturą osobistą.

Wojciech Sokolewicz to także znakomity kompan wieczornych spotkań na konferencjach i zjazdach. Zawsze otoczony wianuszkiem młodzieży i nieco bardziej dojrzałym towarzystwem, swoim niezwykle charakterystycznym tubalnym głosem prowadził «nocne Polaków rozmowy». Degustator wybornych alkoholi, potrafił oczarowywać słuchaczy swoimi opowieściami. 
Konferencja z udziałem Wojtka to był najbardziej udany przepis na merytoryczną dyskusję i udany bankiet.

Cechą Wojciecha Sokolewicza była także ogromna potrzeba pomagania ludziom. Niemal nigdy nie odmawiał prośbom kolegów, nawet jeśli oznaczało to konieczność dalekiej podróży czy spędzenia czasu nad pisaniem recenzji. Szczególne zasługi położył dla rozwoju młodszej kadry naukowej, służąc radą i życzliwą protekcją".

\section{Wspomnienie profesora Zbigniewa Maciąga}

„Prof. dr hab. Wojciech Sokolewicz jako wybitny prawnik i znakomity znawca ustroju Polski oraz ustroju Stanów Zjednoczonych Ameryki był dla mnie nie tylko autorytetem w wielu zwłaszcza złożonych kwestiach prawno-konstytucyjnych, ale także wzorem w zakresie sposobu formułowania myśli, mistrzem argumentacji i precyzyjnego używania terminologii prawniczej. Czułem się wielce zaszczycony, gdy podczas jednej z konferencji naukowych, po wymianie zdań i gorącej dyskusji zaproponował mi pomimo znaczącej różnicy wieku i różnicy w statusie naukowym zejście z płaszczyzny «mistrz-uczeń» na płaszczyznę koleżeńską i zwracanie się do Niego po imieniu. Był to pełen życzliwości gest wyrażający Jego przyjazny stosunek do młodszej kadry naukowej. Dlatego też podczas kolejnych rozmów prowadzonych w kuluarach konferencji czy zjazdów postawiłem Mu jako autorowi kilku opracowań poświęconych zasadzie podziału władz dręczące mnie pytanie, czy Jego zdaniem nie byłoby bardziej prawidłowe sformułowanie «podział władzy» niż «podział władz». Początkowo odpowiedział mi, że jedno i drugie określenie jest prawidłowe i oba mogą być zamiennie stosowane. Odwołałem się jednak do historycznego argumentu, moim zdaniem bowiem przeciwstawne zasadzie podziału, było skupienie władzy w jednym podmiocie, monarchy absolutnego (despocja) - w okresie feudalizmu, czy też bardziej współcześnie w najwyższym przedstawicielstwie, w najwyższej radzie narodowej (Sejmie) - w okresie realnego socjalizmu, kiedy to obowiązywała zasada jedności, jednolitości władzy. Pierwszy podział w poziomie dotyczył jednej, najwyższej władzy, a nie władz, dopiero drugi podział (także w poziomie) odnosił się do każdej z wyodrębnionych już władz i dlatego dalszy podział wewnątrz każdej z nich może być nazwany ogólnie, łącznie «podziałem władz». Posługując się modelem przy- 
jętym w naszej Konstytucji z 1997r. o podziale władz możemy mówić w przypadku podziału władzy ustawodawczej na Sejm i Senat, podziału władzy wykonawczej na Prezydenta Rzeczypospolitej Polskiej i Radę Ministrów oraz podziału władzy sądowniczej na sądy i trybunały. Po chwili zastanowienia, krótkim namyśle, Wojtek powiedział :«Bądźmy zatem już precyzyjni i jednoznacznie powiedzmy: trójpodział władzy, chociaż aż tak precyzyjni nie musimy być». Zgodziłem się z Nim całkowicie”.

\section{Wspomnienie Profesora Jerzego Ciapały}

"Jest mi nader trudno formułować opinie i sądy miarodajne, albowiem nie znałem Pana Profesora osobiście. Stąd jedynie mogę podzielić się jedynie wrażeniami.

Pierwsze z nich prowadzi do wskazania, że był On punktem odniesienia dla wielu autorów: prawników i polityków. Znakomicie łączył wiedzę, erudycję i zdolność krytycznej analizy, co oddziaływało na znakomity standard naukowy Jego opracowań.

Drugie z nich, to wrażenie, iż był bardzo życzliwym Mistrzem i bliskim człowiekiem dla swoich współpracowników. Odniosłem je nie tylko po przeczytaniu wstępu do ostatniej książki «Prasa i Konstytucja», lecz i przede wszystkim podczas obserwacji w czasie wielu spotkań naukowych i towarzyskich.

Trzecie wiąże się z określeniem «dusza towarzystwa»; wśród nawet licznej grupy osób Jego obecność była zauważalna i nie mogło być inaczej. Charyzma osoby, tenor głosu i oryginalność wypowiedzi...I to poczucie humoru.

Wśród mojego i - być może - młodszego pokolenia nie ma chyba przyszłych Uczonych tej klasy.

Cześć Jego pamięci”.

\section{Wspomnienie Profesora Jana Filipa}

„Wiadomość o nieoczekiwanym zgonie profesora Wojciecha Sokolewicza głęboko mnie dotknęła. Odszedł długoletni kolega i mentor wielu czeskich konstytucjonalistów, tych doświadczonych, jak i tych rozpoczynających 
swoją naukową drogę. Na spotkania z Nim cieszył się każdy z nas, ponieważ potrafił doradzić i pomóc. Tym bardziej cieszyłem się w związku ze swoją kwietniową podróżą do Warszawy, licząc, że porozmawiamy jak zawsze. Tak więc nieoczekiwana wiadomość o Jego śmierci była dla mnie ciężkim ciosem. Nie będzie kolejnych spotkań oraz polemik. Na konferencjach nie będą już brzmiały charakterystyczne dla Niego, gruntownie przemyślane wystąpienia, stanowiące swoistą kulminację dyskusji, wygłaszane przy tym donośnym głosem, którego nie można zapomnieć.

Wojciech Sokolewicz był liderem polskich konstytucjonalistów. Pozostanie On dla mnie wzorem uczonego i nauczyciela, który uznaje twardą pracę i wymaga jej od innych. Jego recenzje pozostaną przez długi czas przykładem gruntownej analizy, doskonałej orientacji w sprawie oraz wielkoduszności w konkluzjach. W relacjach międzyludzkich nie był zbyt oficjalny. Często i szybko potrafił znaleźć temat rozmowy, przede wszystkim z młodym pokoleniem polskiego konstytucjonalizmu. Dla mnie, jako cudzoziemca, polska konferencja naukowa kojarzy się z grupką młodzieży (z reguły z przewagą ładnych dziewczyn) wokół profesora Sokolewicza. Było to zrozumiale, ponieważ był to człowiek z dobrym, choć chorym sercem, które nie wytrzymało tragicznego zgonu bliskiej osoby.

Patrzę teraz na otrzymane od Niego życzenie bożonarodzeniowe, w których poruszył wątek wzajemnych relacji polskich oraz czeskich konstytucjonalistów. Szacunek dla nauki prawa konstytucyjnego w Republice Czeskiej dał wyraz swoim podpisem, do którego dopisał (ze znakiem zapytania) «najbardziej czeski z Polaków?». W imieniu czeskich i morawskich konstytucjonalistów pozwałam sobie ten znak zapytania skreślić...”.

\section{Wspomnienie Profesora Mirosława Wyrzykowskiego}

„Ponad czterdzieści lat temu, jako student, miałem możliwość korzystania w czytelni Biblioteki Sejmowej ze zbiorów tej biblioteki. Niewiele było wolnych miejsc przy stołach w czytelni, część bowiem była zawsze zarezerwowana dla posłów, natomiast większość była zajęta przez grono regularnie pracujących w bibliotece pracowników naukowych. Oni mieli swoje stałe miejsca. Do grona tego należeli m.in. Janina Zakrzewska, Jerzy Starościak, An-drzej Gwiżdż, Zdzisław Jarosz, Jan Skupiński, Zbysław Rykowski 
i Wojciech Sokolewicz. Poznawałem wówczas dwa uzupełniające się światy w jakich można było obserwować te osoby: świat skupienia i koncentracji w czytelni i świat ożywionej dyskusji, rozmów, żartów i przyjaznej aury w przerwach na kawę. Profesor Wojciech Sokolewicz wyróżniał się w tym gronie, zarówno potężną sylwetką, jak i energią, tak w nadawaniu tonu rozmowie jak i w sile głosu.

W następnych latach i dziesięcioleciach byłem czytelnikiem publikacji opracowanych przez W. Sokolewicza. Zawsze warto było czekać na jego monografie, artykuły, studia, glosy oraz - także imponujące ilościowo i zakresowo - recenzje książkowe. Jego erudycja zachwycała i onieśmielała rozmówców. Dorobek naukowy W. Sokolewicza jest wzorem metodologicznym badań nad konstytucjonalizmem współczesnym, przykładem ich rzetelności, źródłem wiedzy o problemach, którymi się zajmował, ale także intelektualną inspiracją dla czytelników.

Wielokrotnie spotykaliśmy się przy różnych okazjach. Konferencje, seminaria, zjazdy katedr, przedsięwzięcia wydawnicze których był inicjatorem i skutecznym egzekutorem, spotkania prywatne. Warto było słuchać i wsłuchać się $\mathrm{w}$ to co mówił. Zawsze bowiem $\mathrm{w}$ wypowiedzi zawarty był istotny przekaz. Bez względu na to, czy wypowiedź dotyczyła zagadnień konstytucyjnych, oceny otaczającej rzeczywistości czy spraw prywatnych. Wiedzą i doświadczeniem dzielił się chętnie i mądrze. Autorytet był przesłanką podejmowania rozmów i sporów.

Przywołać chcę zdarzenie sprzed kilkunastu miesięcy. Odbyć się miała konferencja naukowa. Główny bohater konferencji zwraca się do organizatorów z następującą prośbą: «Proszę, by w szczególny sposób zaprosić profesora Wojciecha Sokolewicza. Chciałbym w ten sposób wyrazić mu pamięć i wdzięczność za to, że był człowiekiem, który pomógł mi w wyjątkowo trudnym momencie życia». A zdarzenie, którego dotyczyła rozmowa, miało miej-sce ponad czterdzieści lat temu.

Profesor W. Sokolewicz był także znakomitym kompanem, ceniącym dobrą kuchnię i dobre czerwone wino (ostatnio rozcieńczane wodą) oraz podawanie deserów o właściwym czasie. Także taki obraz pozostanie w pamięci - spotkania towarzyskie, przy różnych bardziej lub mniej oficjalnych okazjach, w czasie których profesor Wojciech Sokolewicz, otoczony grupą młodych ludzi nie tylko jest duszą towarzystwa przy stole, ale jako ostatni schodzi z parkietu”. 


\section{Wspomnienie doktor Ewy Popławskiej}

„Odejście Profesora Wojciecha Sokolewicza, bolesne dla środowiska konstytucjonalistów oraz innych znających Go prywatnie i zawodowo osób, skłania nas wszystkich do podsumowań i refleksji na temat nie tylko wagi Jego naukowego dorobku, ale także naszych z Nim związków. Być może poniewczasie, nie mogę oprzeć się chęci podjęcia polemiki z nietuzinkowym, niezapomnianym Promotorem mojej pracy doktorskiej.

Podczas zorganizowanego przez Instytut Nauk Prawnych PAN w 2002 roku Jubileuszu 70-lecia Profesora Wojciecha Sokolewicza miałam zaszczyt w imieniu Jego uczniów - przedstawiać podziękowanie za opiekę naukową. Ku mojemu wielkiemu zdziwieniu i konsternacji Profesor się mnie wyparł! Stwierdził, że Jego udział w wychowaniu mnie na naukowca, a zwłaszcza w przygotowaniu rozprawy doktorskiej był znikomy. Okoliczności tej deklaracji, a także moje zaskoczenie spowodowały, że nie podjęłam wówczas próby dyskusji. Dzisiaj, z dalszej perspektywy czasowej i wobec nieubłaganych faktów, czuję się w obowiązku odpowiedzieć Profesorowi. Gdyby opieka naukowa oznaczała jedynie regularne spotkania z doktorantem i omawianie kolejnych fragmentów rozprawy, mój Promotor rzeczywiście był od niej daleki. Co wydaje mi się jednak ważniejsze, współpracując z nim i zapoznając się z Jego publikacjami, uczyliśmy się uprawiania nauki.

W badaniach prawnych konsekwentnie wykorzystywał analizę teoretycznoprawną, socjologiczną, prakseologiczną, a zwłaszcza prawnoporównawczą. W latach osiemdziesiątych uświadamiał nam znaczenie patrzenia na instytucje ustrojowe z perspektywy komparatystycznej. To właśnie dogłębna znajomość obcego prawa konstytucyjnego przez Profesora i jego popularyzacja $\mathrm{w}$ polskim piśmiennictwie naukowym pozwoliły $\mathrm{w}$ okresie transformacji systemu politycznego sięgać po sprawdzone wzorce demokracji zachodnich. Znaczący uczestnik prac nad reformą państwa przy Okrągłym Stole oraz ekspert Sejmu i Prezydenta RP, a potem sędzia Trybunału Konstytucyjnego, Profesor Wojciech Sokolewicz był przede wszystkim badaczem o niezwykle szerokiej wiedzy, wykraczającej daleko poza uprawianą dziedzinę nauki. Prace Jego autorstwa cechuje klarowność konstrukcji, bogaty warsztat badawczy oraz piękna polszczyzna, a przede wszystkim oryginalność myśli. Mając świadomość, jak wiele jako autor wymaga od siebie, staraliśmy się tym bardziej nie zawieść Jego oczekiwań, co z jednej strony 
mobilizowało, z drugiej - onieśmielało. Jego uwagi na temat opiniowanych prac były oszczędne, a zarazem niezwykle celne, co mogli docenić nie tylko jego doktoranci czy autorzy recenzowanych prac habilitacyjnych i doktorskich, ale także autorzy publikacji książkowych i artykułów naukowych, których był recenzentem wydawniczym m.in. w trakcie długoletniej współpracy z «Państwem i Prawem». Za uczniów Profesora możemy się jednak także uważać my wszyscy, czytelnicy Jego inspirujących dzieł”.

\section{Wspomnienie doktor Marty Derlatki}

„Profesora Wojciecha Sokolewicza poznałam na XLIV Zjeździe Katedr i Zakładów Prawa Konstytucyjnego w Olsztynie. W corocznym Zjeździe konstytucjonalistów brało udział ponad 100 osób wybitnych Profesorów i uczonych przedstawicieli polskiej doktryny prawa konstytucyjnego. Profesor Sokolewicz wyróżniał się wszystkim: niezwykłym sposobem bycia, dowcipem, otwartością i bezpośredniością. Miał ogromną wiedzę i rzadki dar dzielenia się nią w tak ludzki sposób. Profesor zawsze skupiał wokół siebie młodych ludzi zarażając ich swą pasją do nauki, przyciągając brakiem dystansu. Miał umiejętność mówienia i słuchania innych, był wielkim autorytetem, niedoścignionym wzorem tak w życiu naukowym, jak i towarzyskim. Bywał cyniczny, krytyczny, ale zawsze w Sobie właściwy dowcipny sposób. Trudno jest mówić o Profesorze Sokolewiczu w czasie przeszłym, poprzez twórczość naukową i tak niebagatelną osobowość Profesor pozostanie na zawsze w mojej myśli obecny". 
Profesor Sokolewicz odszedł z Naszego grona, nie uczynił tego jednak w sposób ostateczny i definitywny. Pozostał po Nim ogromny i znakomity dorobek naukowy liczący przeszło pięćset publikacji, w tym kilkanaście pozycji książkowych. Dzieła - jak pisał Jego Przyjaciel, Profesor Jan Wawrzyniak - znakomicie skonstruowane, erudycyjne, przekonywające, pisane piękną, rzadko już spotykaną polszczyzną. To właśnie te wielkie dzieła stanowiące życiową spuściznę Profesora Sokolewicza, będące znakomitym wzorem dla młodszego pokolenia badaczy, jak również liczne wspomnienia, które zachowaliśmy powodują, że Profesor Wojciech Sokolewicz na zawsze pozostanie w pamięci swych bliskich, przyjaciół, uczniów i współpracowników.

Professor, non omnes mortuus!.

Sabina Grabowska Bartłomiej Opaliński 